\title{
Evaluation of noise levels in areas and departments of the upper Technological Institute of Guasave
}

\section{Evaluación de los niveles de ruido en áreas y departamentos del Instituto Tecnológico Superior de Guasave}

\author{
BÁEZ-HERNÁNDEZ， Grace Erandy*†， HUMARÁN-SARMIENTO， Viridiana, \\ RIVERA-RUBIO, Claudia and DELGADO-JIMÉNEZ, Brenda Guadalupe
}

\author{
Instituto Tecnológico Superior de Guasave, Departamento de Ingeniería Industrial \\ ID $1^{\text {st }}$ Author: Grace Erandy, Báez-Hernández / ORC ID: 0000-0003-1580-2199 \\ ID $1^{\text {st }}$ Coauthor: Viridiana, Humarán-Sarmiento / ORC ID: 0000-0003-0071-9181, CVU CONACYT ID: 240153 \\ ID $2^{\text {nd }}$ Coauthor: Claudia, Rivera-Rubio / ORC ID: 0000-0001-5858-7586 \\ ID $3^{\text {rd }}$ Coauthor: Brenda Guadalupe, Delgado-Jiménez / ORC ID: 0000-0002-8289-4823
}

DOI: 10.35429/JHEW.2019.4.3.1.5

Received March 11, 2019; Accepted June 20, 2019

\begin{abstract}
The present experimentation is the evaluation of noise levels in laboratories, classrooms and departments of a Higher Education Institution. Its objective is to identify and evaluate the working conditions to which workers and students are exposed when performing tasks. The study was conducted based on the official Mexican Standard NOM 011-STPS-2001 "Conditions of safety and hygiene in workplaces where noise is generated". Using a TES $1353 \mathrm{~S}$ sound level meter for 4 weeks, evaluating 16 zones, in 2 periods. As a result, it was obtained that 6 of the 16 zones evaluated exceed the maximum permissible exposure limits. And recording discomfort and lack of concentration in the activities to be carried out on workers and students. As a recommendation, the implementation of periodic medical examinations and personal protective equipment for the personnel, in addition to the evaluation of noise levels in the preventive maintenance of the institution.to make the activities more comprehensive.
\end{abstract}

Noise, Environmental Conditions, Preventive Maintenance

\begin{abstract}
Resumen
La presente experimentación es la evaluación de los niveles de ruido en laboratorios, aulas y departamentos de una Institución de Educación de Nivel Superior. Tiene como objetivo identificar y evaluar las condiciones de trabajo a las que están expuestos los trabajadores y alumnos al realizar las tareas. El estudio se realizó con base a la Norma oficial Mexicana NOM 011-STPS-2001 "Condiciones de seguridad e higiene en los centros de trabajo donde se genere ruido". Utilizando un sonómetro TES 1353S durante 4 semanas, evaluando 16 zonas, en 2 periodos. Como resultado se obtuvo que 6 de las 16 zonas evaluadas se sobrepasen los límites máximos permisibles de exposición. $\mathrm{Y}$ registrando molestias y falta de concentración en las actividades a realizar en los trabajadores y alumnos. Como recomendación la implementación de exámenes médicos periódicamente y equipo de protección personal para el personal, además que se considere la evaluación de los niveles ruido en el mantenimiento preventivo de la institución. Para hacer las actividades más integrales.
\end{abstract}

Ruido, Condiciones ambientales, Mantenimiento Preventivo

Citation: BÁEZ-HERNÁNDEZ, Grace Erandy, HUMARÁN-SARMIENTO, Viridiana, RIVERA-RUBIO, Claudia and DELGADO-JIMÉNEZ, Brenda Guadalupe. Evaluation of noise levels in areas and departments of the upper Technological Institute of Guasave. Journal Health, Education and Welfare. 2019. 3-4: 1-5

\footnotetext{
* Correspondence to Author (email: gracebaezh@gmail.com)

$\dagger$ Researcher contributing first author.
} 


\section{Introduction}

Health at work is the multidisciplinary activity that is used for the protection and promotion of safety and health, identifying and eliminating risk factors or conditions that endanger health, and the productive performance of workers in the company.

In Mexico, the Ministry of Labor and Social Welfare is a government agency responsible for the performance of the powers attributed to it by the Federal Public Administration Organic Law, federal labor law, other laws and treaties, as well as regulations, decrees, agreements and orders of the president of the Republic. Among its functions is: Monitor compliance with the provisions contained in art. 123 and others of the Federal Constitution, in the Federal Labor Law and its regulations. As well as study and order industrial safety and hygiene measures for the protection of workers and monitor their compliance. (STPS, Secretary of Labor and Social Security, 2019).

Within the work centers there are work risks. In this regard, social security can distinguish between two types of risks: generic and specific. The first are those to which every person is exposed, while the second are only thinkable with respect to the workers. Within this last group are occupational disease and the risk of an accident at work. (Alonso Olea, 1981).

Ambient noise is one of the most annoying and persistent pollutants in modern society, affecting the population directly. People subjected to noise constantly develop different physiological disorders, such as loss of hearing, alterations in brain, cardiac and respiratory activity, among others. (Bañuelos Castalleda, 2005).

Noise is one of the risks where the worker is exposed most of the time. Therefore, the STPS, generated the Official Mexican Standard NOM-011-STPS-2001, Safety and hygiene conditions in workplaces where noise is generated, in order to know how to identify, analyze and determine the maximum permissible limits to which the worker must be exposed as the duration, type of noise and condition. (STPS, Official Mexican Standard NOM-011-STPS, 2001)

\section{Development}

The Higher Technological Institute of Guasave is committed to improving processes, through compliance with the legal and other requirements of the Integral Management System, in particular the application of OHSAS 18001 (OHSAS-18001: 2007, s.f.). This aims to achieve the orderly management of occupational risk prevention to achieve a work environment, a decrease in absenteeism and increased productivity.

One of the legal requirements is the application of the STPS Legal Framework, within the institution. In accordance with Standard 011-STPS. The evaluation of the work areas and activities carried out by workers who are exposed to the maximum permissible limit was carried out, considering working hours, assigned tasks, duration of activity and frequency.

The Institute has been in constant changes, with the implementation of the 5 certifications among them OHSAS 18001. Same that have been developed in the educational process and integral training of the student. Promoting values and culture preventing pollution from damage and deteriorating health and safety at work. Developing strategies to reduce staff turnover, incidents of workers who have presented in some areas, mainly laboratories, classrooms. Based on this, it is necessary to identify, analyze and propose improvements in working conditions in areas where incidents develop, so that workers do not present health problems due to work risk.

\section{Overall objective}

Evaluate noise levels in areas and departments of the Instituto Tecnológico Superior de Guasave.

\section{Methodology}

The research work was developed in 3 stages: The first was the determination of the evaluation areas within the Institute. The second was the characterization of the evaluation and selection of materials. The third stage was data collection in all areas. 


\section{Determination of evaluation areas}

The workers of the Higher Technological Institute of Guasave carry out their activities in 8-hour days, therefore, Table 1 of Appendix A establishes that for a period of 8 hours of exposure the maximum permissible limit is 90 $\mathrm{dB}(\mathrm{A})$. NER is determined.

\begin{tabular}{|l|l|}
\hline \multicolumn{1}{|c|}{ NER } & \multicolumn{1}{c|}{ TMPE } \\
\hline $90 \mathrm{~dB}(\mathrm{~A})$ & 8 Hours \\
\hline $93 \mathrm{~dB}(\mathrm{~A})$ & 4 Hours \\
\hline $96 \mathrm{~dB}(\mathrm{~A})$ & 2 Hours \\
\hline $99 \mathrm{~dB}(\mathrm{~A})$ & 1 Hour \\
\hline $102 \mathrm{~dB}(\mathrm{~A})$ & 30 Minutes \\
\hline $105 \mathrm{~dB}(\mathrm{~A})$ & 15 Minutes \\
\hline
\end{tabular}

Table 1 Maximum Permissible Exposure Limits and NER Source: NOM-011-STPS-2001

Based on B.6.3. Priority method of evaluation areas, determining the 16 evaluation areas within the institute between classrooms, laboratories, offices, experimental field, teacher's room, green areas, among others.

With a total of 16 zones evaluated, by means of a sensory recognition it was possible to identify stable type noise in all the zones evaluated. Its definition being that which is recorded with variations in its sound level $A$ within a range of $5 \mathrm{~dB}(\mathrm{~A})$.

The type of noise and the method to evaluate it were classified, identifying a stable noise throughout the institution. The evaluation by means of a sound level meter. It is the applicable method when it has been determined, in the sensory recognition, that the noise is stable throughout the working day, and must be carried out during three observation periods.

\section{Characteristics of the evaluation and selection of materials}

A class 1 sound level meter was selected to carry out the experimentation. TES sound meter model 1353S.

The evaluation was carried out for 4 weeks, in the 16 evaluation zones of the Institute. Each observation period lasted a maximum of 5 minutes and 50 readings.

During each observation period the NSA record was taken every 5 seconds.
At each measurement point, the observation periods were carried out approximately every 15 minutes for reasons of staff availability.

The work areas studied were evaluated taking care of a distance between measuring points of no more than 12 meters, in areas below that measure, they were divided into 3 parts and each one was evaluated in different periods.

For the laboratories and areas where the staff is standing, the sound level meter was used at a height of $1.45 \pm 0.1 \mathrm{~m}$, in relation to the lift plane; For the workers who perform their work sitting, the microphone height was placed at head level.

For offices and classrooms where the staff is sitting, the sound level meter was used at head level.

To select the orientation of the sound level meter, the highest noise direction was considered in relation to the location of the main source generating the noise.

\section{Results}

Area and Posts evaluated

\begin{tabular}{|l|l|}
\hline \multicolumn{2}{|c|}{ Evaluated Areas } \\
$\begin{array}{l}\text { 1. Work Study and Ergonomics } \\
\text { Laboratory }\end{array}$ & $\begin{array}{l}2 . \quad \text { Manufacturing } \\
\text { Laboratory }\end{array}$ \\
\hline 3. Mechanics Laboratory & $\begin{array}{l}\text { 4. Biochemistry } \\
\text { Laboratory }\end{array}$ \\
\hline 5. Unit Operations Laboratory & $\begin{array}{l}\text { 6 Food Technology } \\
\text { Laboratory }\end{array}$ \\
\hline 7. Offices building A & 8. Offices building B \\
\hline 9. Offices building C & 10. Building classroom E \\
\hline 11. Cafeteria & 12. Computer center 1 \\
\hline 13. Teachers Room & 14. Audiovisual Room \\
\hline 15. Experimental Field & $\begin{array}{l}\text { 16. Green areas - Act of } \\
\text { Intent }\end{array}$ \\
\hline
\end{tabular}

Table 2 Areas evaluated in the Institute Source: Own Creation

Measurements were made throughout the institute, evaluating 16 zones, each of them in 3 periods of time, making 50 readings per period. To obtain the NSA average, from each zone as established by the Official Mexican Standard of NOM-011-STPS-2001. 


\begin{tabular}{|c|c|c|}
\hline Num & Ubicación Nivel sonoro A calculado & $\begin{array}{c}\text { NSA } \\
\text { Calculated }\end{array}$ \\
\hline 1 & $\begin{array}{l}\text { Laboratory of Work Study and } \\
\text { Ergonomics }\end{array}$ & $73.701 \mathrm{DB}$ \\
\hline 2 & Manufacturing Laboratory & $80.201 \mathrm{DB}$ \\
\hline 3 & Mechanics Laboratory & $92.703 \mathrm{DB}$ \\
\hline 4 & $\begin{array}{l}\text { Biochemistry and Microbiology } \\
\text { Laboratory }\end{array}$ & $84.312 \mathrm{DB}$ \\
\hline 5 & Chemical Engineering Laboratory & $\begin{array}{l}102.418 \\
\text { DB }\end{array}$ \\
\hline 6 & Food Technology Laboratory & $\begin{array}{l}101.210 \\
\text { DB }\end{array}$ \\
\hline 7 & Building A offices & $68.340 \mathrm{DB}$ \\
\hline 8 & Building B offices & $66.300 \mathrm{DB}$ \\
\hline 9 & $\mathrm{C}$ building offices & $67.400 \mathrm{DB}$ \\
\hline 10 & Classroom building E & $68.250 \mathrm{DB}$ \\
\hline 11 & Coffee shop & $69.300 \mathrm{DB}$ \\
\hline 12 & Computer Center 1 & $68.700 \mathrm{DB}$ \\
\hline 13 & Teachers room & $68.310 \mathrm{DB}$ \\
\hline 14 & Audiovisual room & $68.803 \mathrm{DB}$ \\
\hline 15 & Experimental field & $84.290 \mathrm{DB}$ \\
\hline 16 & Green areas & $81.200 \mathrm{DB}$ \\
\hline
\end{tabular}

Table 3 NSA table calculated by Zone evaluated in the Institute

Source: Own Creation

\begin{tabular}{|c|c|c|}
\hline Num & Location & $\begin{array}{c}\text { NER } \\
\text { Calculated }\end{array}$ \\
\hline 1 & $\begin{array}{l}\text { Laboratory of Work Study and } \\
\text { Ergonomics }\end{array}$ & $73.508 \mathrm{DB}$ \\
\hline 2 & Manufacturing Laboratory & $80.900 \mathrm{DB}$ \\
\hline 3 & Mechanics Laboratory & $92.703 \mathrm{DB}$ \\
\hline 4 & $\begin{array}{l}\text { Biochemistry and Microbiology } \\
\text { Laboratory }\end{array}$ & $85.400 \mathrm{DB}$ \\
\hline 5 & Chemical Engineering Laboratory & $\begin{array}{l}101.210 \\
\text { DB }\end{array}$ \\
\hline 6 & Food Technology Laboratory & $\begin{array}{l}101.200 \\
\text { DB }\end{array}$ \\
\hline 7 & Building A offices & $68.200 \mathrm{DB}$ \\
\hline 8 & Building B offices & $70.000 \mathrm{DB}$ \\
\hline 9 & $\mathrm{C}$ building offices & $67.400 \mathrm{DB}$ \\
\hline 10 & Classroom building E & $68.200 \mathrm{DB}$ \\
\hline 11 & Coffee shop & $70.000 \mathrm{DB}$ \\
\hline 12 & Computer Center 1 & $68.700 \mathrm{DB}$ \\
\hline 13 & Teachers room & $68.500 \mathrm{DB}$ \\
\hline 14 & Audiovisual room & $68.803 \mathrm{DB}$ \\
\hline 15 & Experimental field & $84.290 \mathrm{DB}$ \\
\hline 16 & Green areas & $81.700 \mathrm{DB}$ \\
\hline
\end{tabular}

Table 4 NER table calculated by Zone evaluated in the Institute

Source: Own Creation

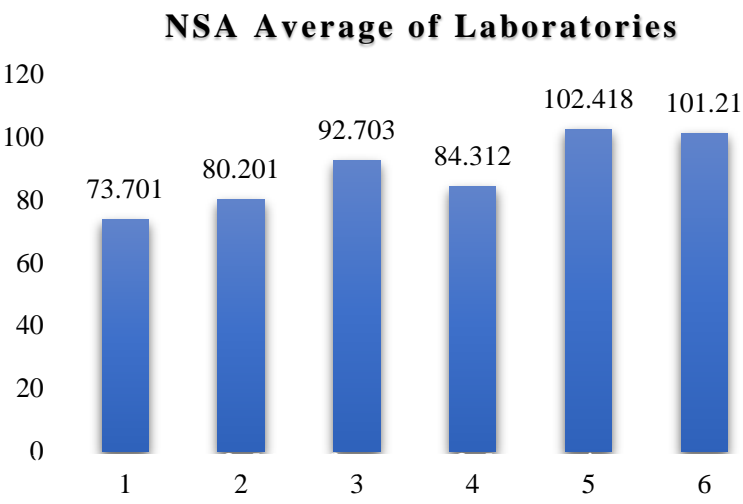

Graph 1 NSA Average of Laboratories of the Institute Source: Own Creation

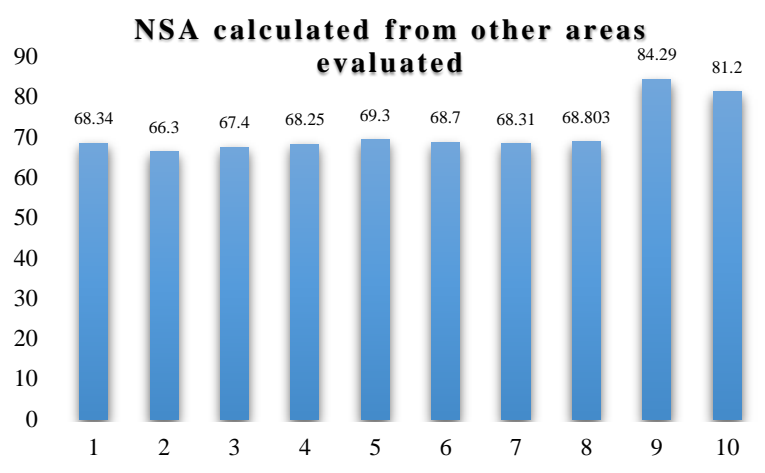

1.- Offices Building A, 2. Offices Building B, 3.- Offices Building C 4.Classrooms in Building E 5.- Cafeteria 6. Computing Center 1, 7.

Teachers Room 8. Audiovisual Room 9. Experimental Field 10. Green

Graph 2 NSA calculated from other evaluated areas of the Institute

Source: Own Creation

It detects 6 zones that go above 80 decibels allowable by NOM-011-STPS-2001. There are 5 mechanics laboratory, technology and food laboratory, chemical engineering laboratory, biochemistry and microbiology laboratory, green areas and experimental field.

\section{Thanks}

The research is the product of an internal research project that was developed at the Instituto Tecnológico Superior de Guasave, from January 1, 2018 to December 31, 2018, as well as financing and management was carried out by the authorities of the Institute. I appreciate the support to the 3 collaborators, and participating students.

\section{Conclusions}

At the end of the investigation, the NSAs were calculated and 6 zones of 16 were detected that require changes immediately. Mainly in laboratories where it is greater than $80 \mathrm{~dB}$.

Within these areas, 3 of them have decibels above 85 , mechanical laboratory, food and technology laboratory, chemical engineering laboratory.

No zone evaluated has $\mathrm{dB}$ greater than $105 \mathrm{~dB}$. In general, no person is exposed to hearing problems, because there are no long periods of exposure. 6 people are exposed to considerable noise levels at least during an internship during the holiday season and 3 people at high levels. 


\section{Suggestions}

One of the suggestions is the use of personal hearing protection equipment, in accordance with the provisions of NOM-017-STPS-1993, to all exposed workers equal to or greater than 85 $\mathrm{dB}(\mathrm{A})$, when they carry out their practices in laboratories. As well as conducting specific annual medical exams for each worker exposed to levels above $85 \mathrm{~dB}$. (TO).

Noise exposure time is considered vital to avoid hearing problems and physical and cognitive injuries in workers.

\section{References}

Abal, L. T. (2011 ). Ruido ambientla, seguridad y salud . Revista de Ciencia y Tecnología y Medio Ambiente , 1-24.

Alonso Olea, M. (1981). Fuentes de la relacion laboral y criterio de aplicación. Madrid: Instituto de Estudios Sociales, Ministerio de Trabajo, Sanidad y Seguridad Social.

Bañuelos Castalleda, M. (2005). Analisis de los niveles de ruido ambiental por trafico vehicular en puntos criticos de la zona metropolitanade Guadalajara Jalisco, Mexico y actualización del mapa de ruido. Mexico.

Behar, A. (1994). El ruido y su control. Mexico : Trillas SA de CV.

Figueroa Montaño, A., Orozco Medina, M. G., \& Preciado Caballero, N. E. (2012). Niveles de ruido y su relación con el aprendizaje y la percepción en escuelas primarias de Guadalajara, Jalisco, México. Ingeniería, 175181.

IMSS. (2003). Memoria Estadistica 2002

Capitulo VI. Obtenido de http://www.imss.gob.mx/IMSS/IMSS_SITIOS/ DPF/DPFDIF/estadisticas/memoria/2002/estadi sticas_ST02_001_2003_12.htm

Moreno Ceja , F., Orozco Medina, M. G., \& Zumaya, L. M. (2014). Los niveles de ruido en una biblioteca universitaria, bases para su analisis y discusión. Bibliotecológica, 197-224.

OHSAS-18001:2007. (s.f.). Obtenido de https://www.isotools.org/pdfs-pro/ebook-ohsas18001-gestion-seguridad-salud-ocupacional.pdf
STPS. (2001). Norma Oficial Mexicana NOM011-STPS. Cd. Mexico, Mexico: Diario Oficial de la Federación. Obtenido de http://stps.gob.mx/bp/secciones/dgsst/normativi $\mathrm{dad} /$ normas/Nom-011.pdf

STPS. (05 de Junio de 2019). Secretaria de Trabajo y Prevensión Social. Obtenido de https://www.gob.mx/stps 